\title{
THE EFFECTS OF WOOD VINEGAR ON SOME SOIL MICROORGANISMS
}

\author{
Koç, I. $^{1 *}-$ ÖĞÜN, E. ${ }^{2}-$ NAMLI, A. ${ }^{3}-$ MendEŞ, M. ${ }^{4}-$ KutLU, E. ${ }^{3}-$ YARDIM, E. N. ${ }^{5}$ \\ ${ }^{I}$ Department of Environmental Engineering, Faculty of Engineering and Architecture, Bitlis \\ Eren University, 13000 Bitlis, Turkey \\ ${ }^{2}$ Department of Molecular Biology and Genetics, Faculty of Science, Van Yüzüncü Yıl \\ University, 65000 Van, Turkey \\ (e-mail:erdalogun@hotmail.com) \\ ${ }^{3}$ Department of Soil Science and Plant Nutrition, Faculty of Agriculture, Ankara University \\ 06030 Ankara, Turkey \\ (e-mails: aytenkrc@gmail.com-A.Namli; esrakutlu44@gmail.com-E.Kutlu) \\ ${ }^{4}$ Faculty of Agriculture, Çanakkale Onsekiz Mart University, 17000 Çanakkale, Turkey \\ (e-mail: mehmetmendes@gmail.com) \\ ${ }^{5}$ Bitlis Eren University Rectorship, 13000 Bitlis, Turkey \\ (e-mail: enyardim@beu.edu.tr) \\ *Corresponding author \\ e-mail: ibrahimkoc47@gmail.com; phone: +90-434-228-0075; fax: +90-434-222-0101 \\ (Received $14^{\text {th }}$ Oct 2018; accepted $2^{\text {nd }}$ Jan 2019)
}

\begin{abstract}
This study was carried out in order to determine the enzyme activity of the wood vinegar obtained from the hazelnut shells with the potential of bio-pesticide in agro-ecosystem soil, and its effect on the microfungi and heterotrophic bacteria in total. The study was realized in the production seasons of 2014-2015 and 2015-2016, in the ecological conditions of the province Muş (in Turkey) on winter wheat field and with four repetitions according to Randomized Blocks Experimental Design. The treatments within the scope of the experiment were conducted as the six different doses of wood vinegar at $0.5 \%$, $1.0 \%, 2.0 \%, 3.0 \%, 4.0 \%$, and $5.0 \% \mathrm{~mL}$, and the control treatment which was only provided with tap water. Repeated Measurement ANOVA was used to determine the effect of wood vinegar at different doses, the production seasons and periods (pre- and post-treatment) on relevant features. As based on the statistical inferences, only the Treatment $\times$ Year and Period $\times$ Year interaction effects in terms of the number of heterotrophic bacteria $(\mathrm{P}=0.000$ and $\mathrm{P}=0.011)$; and only the Period $\times$ Year interaction effects for the number of microfungi $(\mathrm{P}=0.000)$ were found statistically significant. Therefore, the effect of the treatments made on the number of heterotrophic bacteria varied by the production seasons. In a similar way, the effect of the production season and periods on the number of microfungi also changed as based on the term. While the effect of period $(P=0.000)$ and the Treatment $\times$ Period interaction $(P=0.014)$ effect were significant for Alkaline Phosphatase activity, Year $\times$ Period $(P=0.001)$ and Treatment $\times$ Period interactions $(\mathrm{P}=0.000)$ were found significant as related to Beta Glucosidase activity. In conclusion, it may be stated that the wood vinegar used at different doses with the purpose of protecting plant and/or crop in wheat agro-ecosystem does not have a negative effect on microbial factors determined in the soil, and especially, the treatment of $3 \% \mathrm{~mL}$ has a positive effect on bacteria number and Beta Glucosidase enzyme activity.
\end{abstract}

Keywords: agroecosystem, heterotrophic bacteria, microfungi, soil enzyme activities, wood vinegar

\section{Introduction}

The primary objective of agricultural practices is to obtain abundant and high-quality crops without disturbing ecological balances (Topal, 2011). Within the scope of 
sustainable plant protection studies, herbal products may have a considerable part as stabilizer for synthetic pesticides or effecting the actions of synthetic pesticides in soil (Hagner, 2013). In the production of herbal pesticides, a variety of plants and various technologies have been used (Tiilikkala et al., 2011). Wood vinegar (WV) and other weak pyrolysis liquids are produced as a by-product of carbonization processes, and in the archeological studies carried out so far, it has already been detected that they were used in the Neanderthal's era (Tiilikkala et al., 2010). WV consists of water by $80-90 \%$ and the rest amount is of more than 200 organic compounds (Kim et al., 2008). The main components of $\mathrm{WV}$ are acetic acid and also organic acids, phenolic, alkane, alcohol and ester compounds (Jothityangkoon et al., 2008). WV is a substance that is toxic or slightly toxic to the non-target organisms in water and soil (Hagner, 2013). It has been detected that WV obtained from Vitex pubescens displayed antifungal effect (Orahami and Yoshimura, 2013). Baimark and Niamsa (2009) stated that WV could restrain the growth of fungus, as its involving strong phenolic compounds. Velmurugan et al. (2009) found out that the neutralized WV showed a strong antifungal effect. Jothityangkoon et al. (2008) detected that the contamination decreased, in their studies for the effect of WV on fungi producing aflatoxine. Namli et al. (2014) stated that the case in which $\mathrm{WV}$ is treated as biocide in in-vivo conditions would provide beneficial outcomes, in accordance with the data they have already obtained in in-vitro conditions. Orahami et al. (2018) indicated in their studies that WV has had antifungal effect. Eric et al. (2012) stated that distilled and non-distilled WV had inhibited the bacteria. WV can activate the edaphon number in a short time and at maximum, and also has a promoting role in increasing the number of bacteria especially in the root parts of vegetables (Shi, 2003). Duan et al. (2016) put forth that the four types of WV, which they had involved in their studies, had a strong blocking effect on three sorts of bacteria. In plant protection activities, WV stands for a promising solution in terms of preventing the growth of pathogenic bacteria and fungi (Chalermsan and Peerapan, 2009). Lee et al. (2010), in their studies, pointed out that WV had a strong antimicrobial effect. Additionally, it was stated that the applied WV treatments had increased the phosphatase, protease, urease and invertase enzyme activities (Aleandri et al., 2012). It was also observed that the WV application at different concentration in sandy soil created an effect on microbial biomass and enzyme activity ( $\beta$-Glucosidase, alkaline phosphatase and dehydrogenase) (Du et al., 2016). Koç et al. (2018) detected that WV was promising in increasing the enzyme activities in some of its applications. We consider that the determination of the most effective and appropriate WV dose is a highly important issue for plant protection activities. In this way, to maintain a pest control process without using any chemical substance will become possible. The objective in this research is to determine the effect of the wood vinegar obtained by means of the carbonization of hazelnut shells in the potential of bio-pesticide on alkaline phosphatase and beta glucosidase enzyme activities, bacteria and microfungi populations in agro-ecosystem soil.

\section{Materials and methods}

This study has been carried out in Krasunia odeska wheat field that belongs to BERCE Alparslan Agricultural Administration (height: 1276, lateral: 380 47' 33 . 1815", long: 41032 ' 45. 700") located at a distance of $12 \mathrm{~km}$ to the central part of the province Muş (in Turkey) (Fig. 1). The study was made in accordance with the 
Randomized Block Design and with four repetitions. Each parcel in experiment has the size of $25 \mathrm{~m}^{2}$ and at least a 2-m-gap was spaced out between blocks and parcels (Anonymous, 2016a). The treatments made in the experiment was realized in the way of six different doses of $\mathrm{WV}$ at $0.5 \%, 1.0 \%, 2.0 \%, 3.0 \%, 4.0 \%$ and $5.0 \% \mathrm{~mL}$, and the control provided with tap water only. WV treatments were carried out as to the schedule for fertilizing and agricultural spraying by BERCE Alparslan Agricultural Administration. Treatments were made by means of $16 \mathrm{~L}$ backpack sprayer (AnadoluPower APW-16, mode of operation: mechanical/operating by side pressing, filling chamber with filter, having an internal tank stirrer, can spray the liquid up to a maximum distance of $4 \mathrm{~m}$, with an adjustable nozzle at 4 different types, $2.70 \mathrm{~kg}$ in weight). The classification by the texture of soil in the experimental area is argillaceous soil with the rate of clay by $63.29 \%$, silt ratio by $25.8 \%$ and sand ratio by $10.9 \%$ (Koç, 2017). The climatic data of the research area, respectively, the $1^{\text {st }}$ year (2014-2015), the $2^{\text {nd }}$ year (2015-2016) and areal precipitation, average temperature and average relative humidity values of the last decade (long period average) were presented in Table 1 (Anonymous, 2016b).
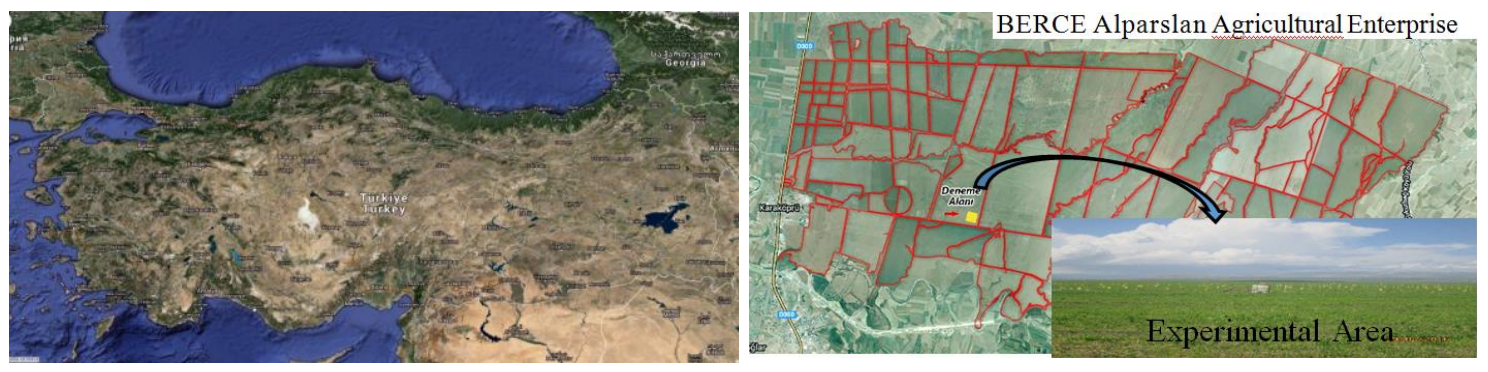

Figure 1. Experimental area

Table 1. Some climate data for 2014-15, 2015-16 years and last ten years (LTY) in Muş province

\begin{tabular}{c|c|c|c|c|c|c|c|c}
\hline \multicolumn{3}{c|}{ Total rainfall $(\mathbf{m m})$} & \multicolumn{3}{c|}{ Mean temperature $\left({ }^{\circ} \mathbf{C}\right)$} & \multicolumn{3}{c}{ Mean relative humidity (\%) } \\
\hline $2014-15$ & $2015-16$ & LTY & $2014-15$ & $2015-16$ & LTY & $2014-15$ & $2015-16$ & LTY \\
\hline 740.4 & 790.1 & 740.5 & 11.55 & 11.48 & 10.62 & 55.02 & 54.00 & 60.79 \\
\hline
\end{tabular}

Wood vinegar (WV) used in this study has been supplied from an establishment developing bio-coal and wood vinegar products by the gasifier of hazelnut shells (Naml1 et al., 2014). Wheat seeds were sown by No-Till method. Inputs used in the treatment: bottom fertilizer (NP 20-20-0, $13.700 \mathrm{~g} / \mathrm{da}$ ) upon sowing on the $16^{\text {th }}$ October of 2014 and height fertilizer in bolting period (46\% urea, $10 \mathrm{~kg} / \mathrm{ha}^{-1}$ ) were applied. Furthermore, on the $26^{\text {th }}$ May of 2015, to the parcels for which WV was applied, WV at different doses and to the control parcels only tap water was applied. Upon sowing, on the $12^{\text {th }}$ September of 2015, bottom fertilizer (NP 20-20-0, $13.7 \mathrm{~kg} / \mathrm{ha}^{-1}$ ) and height fertilizer in bolting period ( $46 \%$ urea, $10 \mathrm{~kg} / \mathrm{ha}^{-1}$ ) were applied. Moreover, to the parcels which WV was applied on the dates of April $24^{\text {th }}$, April $30^{\text {th }}$, May $8^{\text {th }}$ and June $6^{\text {th }}$, 2016, WV application at different doses was performed and the control parcels were provided with only tap water. The average humidity (\%) content of soil samples in the experimental area was detected (Table 2). 
Table 2. Average amount of moisture (\%), according to production seasons in the experimental area

\begin{tabular}{c|c|c}
\hline Years & Sample time & Average moisture (\%) \\
\hline \multirow{2}{*}{$\mathbf{2 0 1 4 - 2 0 1 5}$} & 19.05 .2015 & 24.90 \\
& 25.06 .2015 & 19.60 \\
\hline \multirow{2}{*}{$\mathbf{2 0 1 5 - 2 0 1 6}$} & 21.04 .2016 & 27.97 \\
& 25.06 .2016 & 16.27 \\
\hline
\end{tabular}

Soil sampling process involved the soil samples obtained from 8 different parts of each parcel (Yardim, 1996) by means of nematode sampling instrument (from a depth of 10 to $30 \mathrm{~cm}$ ), and those samples taken were blended well to be aggregated. Samples were collected in sterile polyethylene nylon bags and preserved at $+4{ }^{\circ} \mathrm{C}$ in the laboratory for further analysis. Treatments were realized once in 2014-2015 and four times in 2015-2016. The determination of humidity percentage in soil samples according to Craze (1990), the detection of total number of microfungi and bacteria according to Benson (2001), and the determination of Beta-glucosidase and Alkaline phosphatase enzyme activities were done according to Naseby et al. (1997). Repeated Measurement ANOVA has been used in analyzing data sets. Analysis results have presented as graphically (Figs. 2-8). All statistical analyses have been performed by using IBM SPSS (Ver. 24).

Statistical model used for analyzing data set was:

$$
\mathrm{Yijkl}=\mu+\alpha \mathrm{i}+\beta \mathrm{j}+\alpha \beta \mathrm{ij}+\pi \mathrm{l}(\mathrm{ij})+\gamma \mathrm{k}+\alpha \gamma \mathrm{ik}+\beta \gamma \mathrm{jk}+\alpha \beta \gamma \mathrm{ijk}+\gamma \pi \mathrm{kl}(\mathrm{ij})+\varepsilon \mathrm{m}(\mathrm{ijkl})
$$

Yijkl: observed value for the number of heterotrophic bacteria, the number of microfungi and enzyme activity in k period of lth experimental unit of jth year in the ith treatment,

$\mu$ : overall population mean,

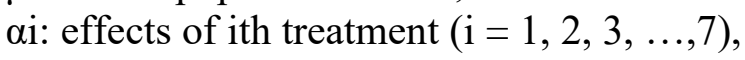

$\beta \mathrm{j}$ : effects of $\mathrm{jth}$ year $(\mathrm{j}=1,2)$,

$\alpha \beta \mathrm{ij}$ : treatment by year interaction,

$\pi$ l(ij): random effect of the experimental unit 1 in ith treatment and jth year, $\gamma \mathrm{k}$ : effect of $\mathrm{k}$ th period $(\mathrm{k}=1=$ before, $\mathrm{k}=2$ after $)$,

aүik: treatment by period interaction,

$\beta \gamma \mathrm{jk}$ : year by period interaction,

$\alpha \beta \gamma \mathrm{ijk}$ : treatment $\times$ year $\times$ period interaction,

$\gamma \pi \mathrm{kl}(\mathrm{ij})$ : experimental unit 1 by period interaction in ith treatment and jth year, $\varepsilon$ m(ijkl): random error term (Mendeş, 2013).

\section{Results and discussion}

Repeated Measurement ANOVA has been used for investigating effect of WV applications on the number of heterotrophic bacteria, the number of microfungi and enzyme activity (Winer et al., 1971; Mendeş, 2013). And the results of the Repeated Measurement ANOVA have been presented below: 


\section{Effect of wood vinegar treatments on the number of heterotrophic bacteria}

As based on the repeated measurement ANOVA results, only Treatment $\times$ Year and Period $\times$ Year interaction effects have been found statistically significant $(\mathrm{P}=0.000$ and $\mathrm{P}=0.011)$. Therefore, the effects of treatments on heterotrophic bacteria have varied by years (2014-2015 and 2015-2016). Similarly, on the basis of period (pre- and posttreatment), the effect of year on heterotrophic bacteria have also differed. Treatment $\times$ Year and Period $\times$ Year interaction have been presented in Figures 2 and 3, respectively. As is seen in Figure 2, it has been determined that WV is effective in the treatments for 2014-2015 in terms of the decrease in heterotrophic bacteria, and however, there have been great differences in the case for 2015-2016.

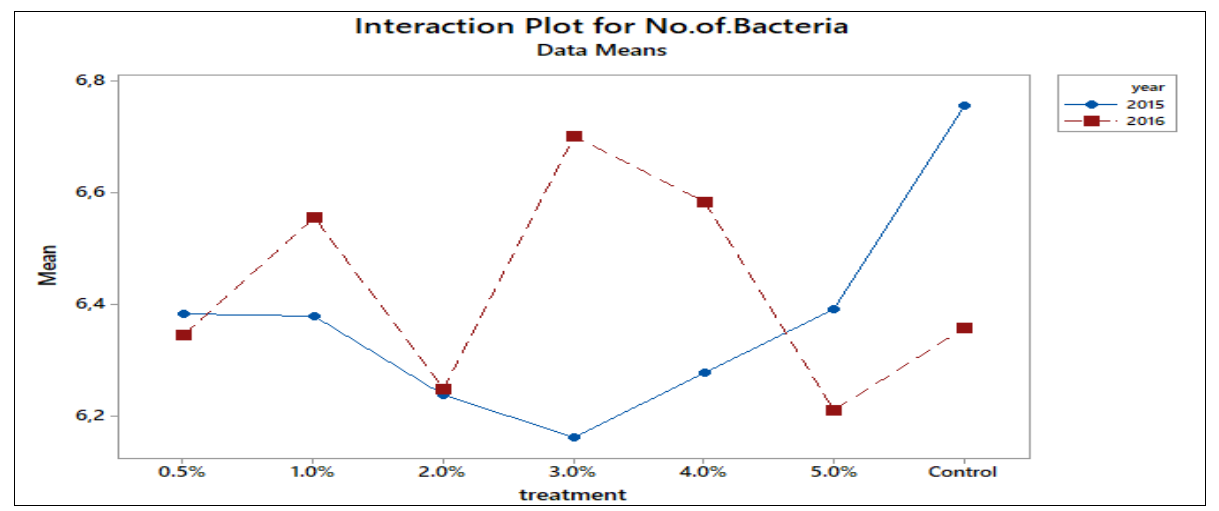

Figure 2. Interaction plot for treatment by year in terms of number of heterotrophic bacteria

When the Period $\times$ Year interaction plot is analyzed (Fig. 3), it is seen that the number of bacteria before the treatment in 2014-2015 is a bit more than the number of bacteria after the treatment. On the other hand, it can be observed that the posttreatment bacteria number in 2015-2016 is considerably more than the number for pretreatment.

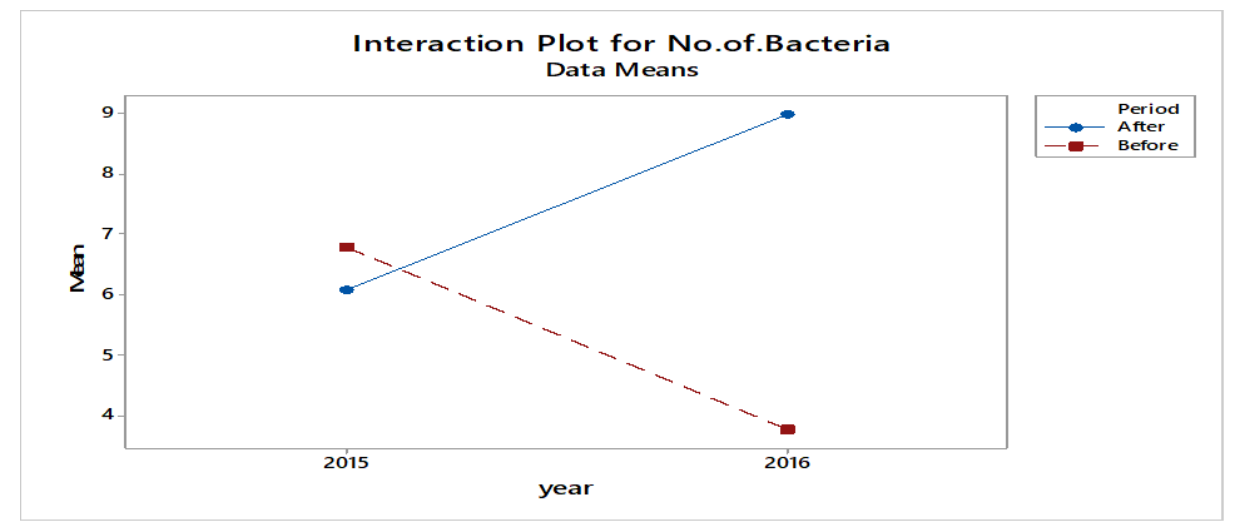

Figure 3. Interaction plot for period by year in terms of number of heterotrophic bacteria

\section{Effect of wood vinegar treatments on the number of microfungi}

Based on the Repeated Measurement ANOVA results, it has been seen that the only Period $\times$ Year interaction effect is statistically significant $(P=0.000)$. For this reason, 
the effect of year on the number of microfungi has varied by the period (before and after treatment). The Period $\times$ Year interaction plot is given in Figure 4. As it is seen in this plot, microfungi number in 2014-2015 is rather more, when compared to the period by 2015-2016, independently of treatment number. It is realized that the number of microfungi after treatment in 2015-2016 is greater than it is in 2014-2015.

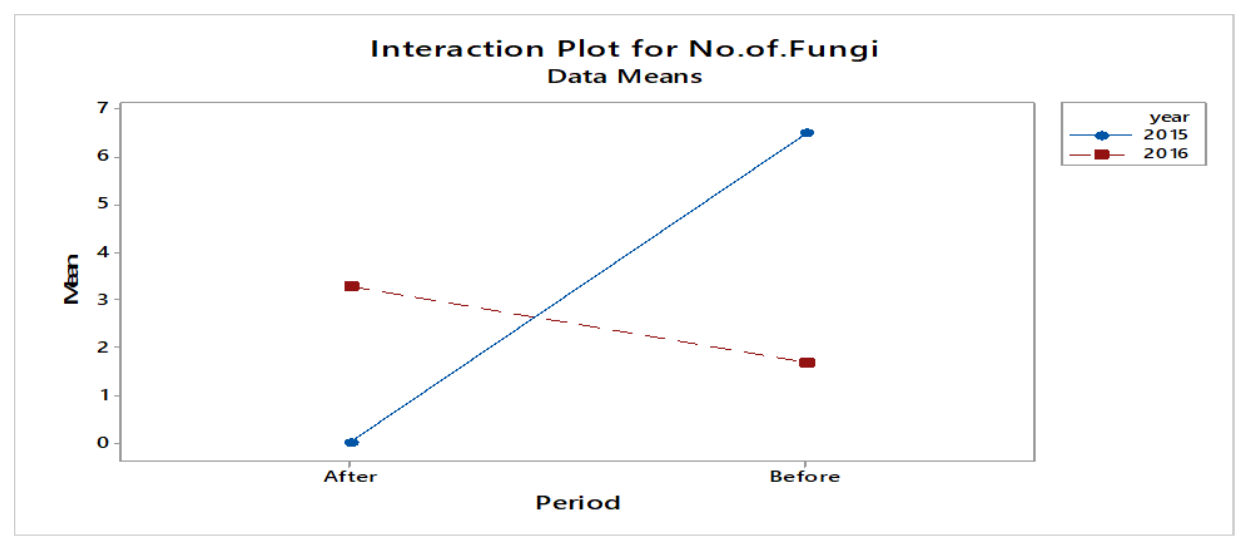

Figure 4. Interaction plot for period by year in terms of number of microfungi

\section{Effect of wood vinegar treatments on enzyme activity}

Considering the results of statistical analysis, it has been seen that the period effect $(\mathrm{P}=0.000)$ and Treatment $\times$ Period interaction $(\mathrm{P}=0.014)$ is significant. Therefore, the effects of treatments on Alkaline Phosphatase activity have varied by period (before and after treatment). Main effect plot for period and Treatment $\times$ Period Interaction plot are provided in Figures 5 and 6, respectively.

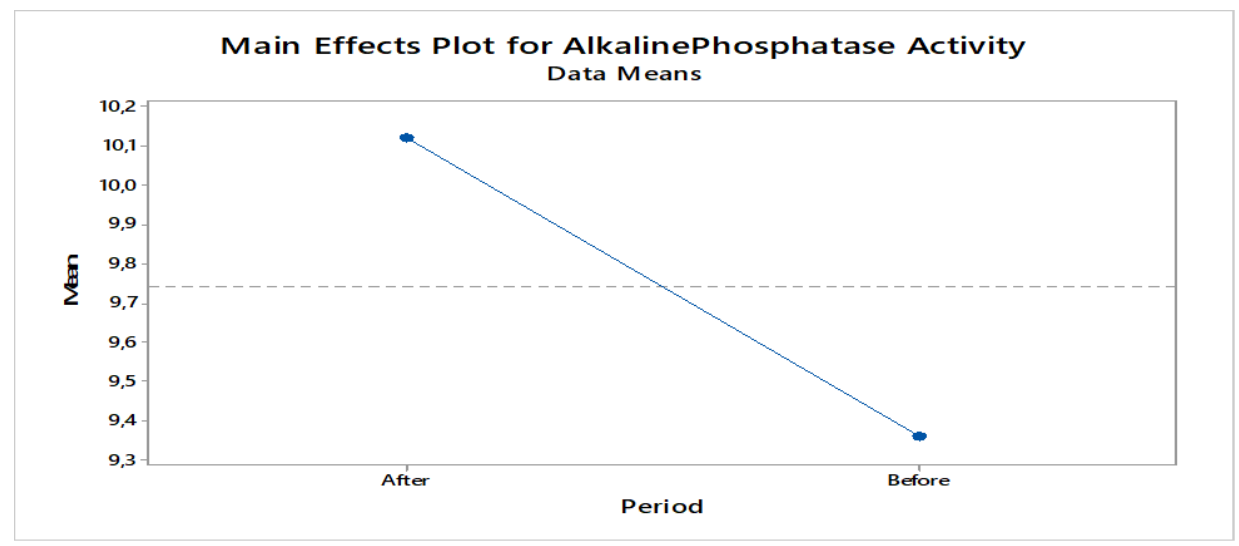

Figure 5. Main effect plot for period in terms of alkaline phosphatase activity

As it can be seen in Figure 5, the value of Alkaline Phosphatase activity after treatment is significantly higher than before treatment, independently of year and treatments. Treatment $\times$ Year interaction effect plot is given in Figure 6 . When Figure 6 is considered, the value of Alkaline Phosphatase activity has varied by treatments and years. However, the Alkaline Phosphatase activity at maximum is gained from the WV treatment of $1.0 \% \mathrm{~mL}$, in 2014-2015. For 2015-2016, the highest value was obtained 
from the control treatment. As the reason for these results, it has been estimated that the case may be based on the extent, namely the highest, of WV doses used.

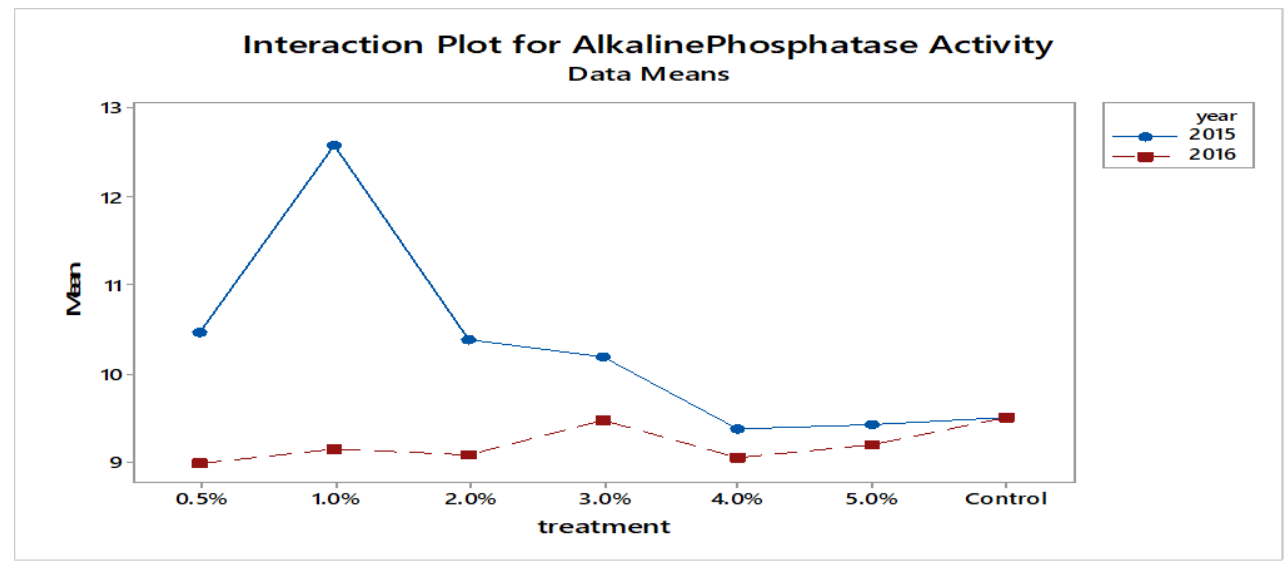

Figure 6. Interaction plot for treatment by year in terms of alkaline phosphatase

ANOVA results as related to Beta Glucosidase activity have revealed that Year $\times$ Period $(\mathrm{P}=0.001)$ and Treatment $\times$ Period interactions $(\mathrm{P}=0.000)$ are statistically significant. Therefore, the effect of year and treatments on Beta Glucosidase activity has varied by period (before and after treatment). Interaction plots for Year $\times$ Period and Treatment $\times$ Period are presented, respectively, in Figures 7 and 8 . As it can be seen in Figure 7, the difference between pre-treatment and post-treatment is rather obvious, especially in 2015-2016.

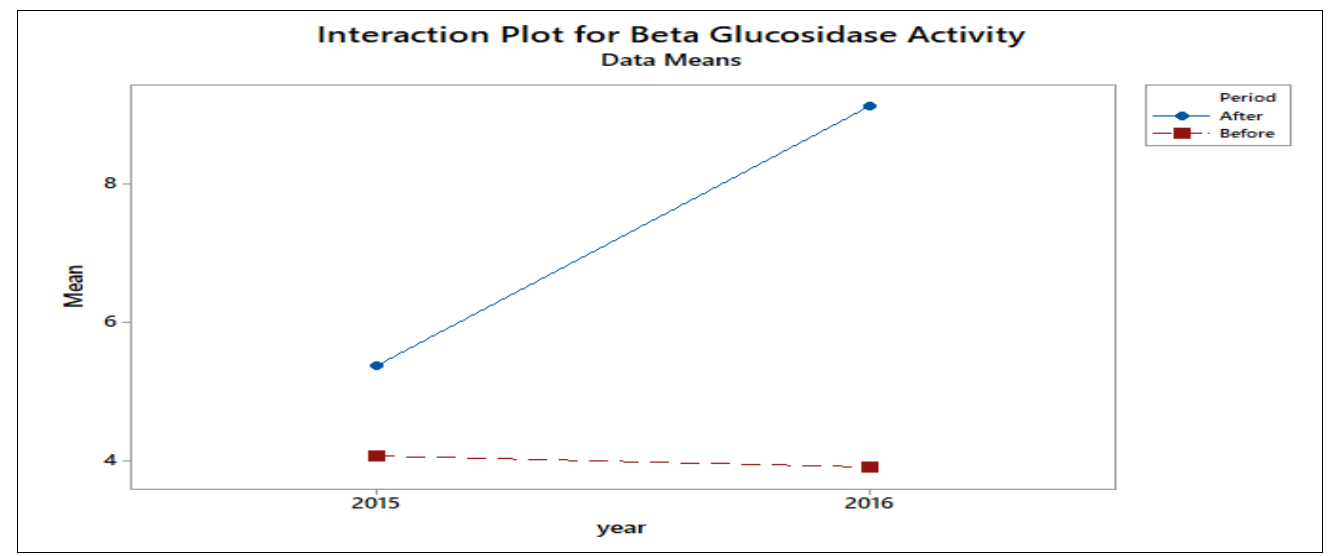

Figure 7. Interaction plot for period by year in terms of beta glucosidase activity

When the effect of treatments on Beta Glucosidase activity is considered (Fig. 8), it is seen that Beta Glucosidase activity has varied by treatment and years. In addition to this, while the highest value of Beta Glucosidase activity has been gained from the $3.0 \%$ $\mathrm{mL}$ treatment for the year 2014-2015, the maximum value for Beta Glucosidase activity has been received in the control treatment for 2015-2016. This result, as is in Alkaline Phosphatase activity, is thought to be arisen from that WV doses have been applied at higher levels, as well. 


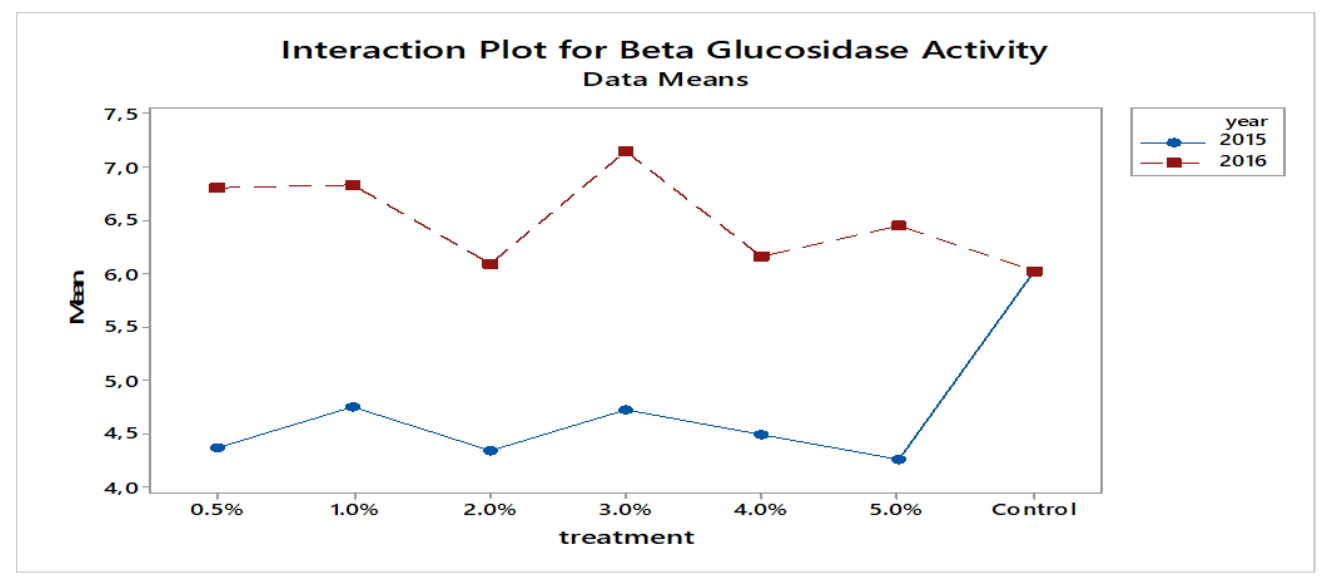

Figure 8. Interaction plot for treatment by year in terms of beta glucosidase

The utilization of bio-pesticides in agricultural practices as an alternative to the common pesticides is essential with regard to secure food, preservation of biological diversity and prevention of environmental pollution. In this study, the probable effect of wood vinegar obtained from the carbonization of hazelnut shells having the biopesticide potential on some microbial factors in agro-ecosystem soil has been investigated. It is realized that the findings reached at within the scope of this study are supported by the results of some similar studies that have been carried out before. For instance, the obtained findings as being relevant to the number of heterotrophic bacteria share similarity with the results in Shi (2003); however, it has been detected that they indicate some differences compared to the studies carried out by Nurhayati et al. (2005), Chalermsan and Peerapan (2009), Mao et al. (2010), Eric et al. (2012) and Duan et al. (2016). It has been thought that these differences may result from the changes related to the specific conditions, like climatic conditions, in the experimental area. When considered in terms of microfungi, especially in the production season of 2014-2015, it has been determined that WV treatments have effect on the decrease in the number of microfungi. Also, it has been noticed that the results similar to these findings have already been reached in the studies by Jothityangkoon et al. (2008), Baimark et al. (2008), Baimark and Niamsa (2009), Chalermsan and Peerapan (2009), Velmurugan et al. (2009), Lee et al. (2010), Ibrahim et al. (2013), Oramahi and Yoshimura (2013), Saberi et al. (2013), Namli et al. (2014), Chuaboon et al. (2016), Ahadiyat et al. (2018) and Oramahi et al. (2018). It has been observed that the effect of WV treatments applied in this study on the enzyme activities (Alkaline phosphatase and Beta-glucosidase) varies according to before and after treatment. However, it is understood that the enzyme activities generally increase after WV treatments, and similar results have also revealed in the studies by Aleandri et al. (2012) and Koç et al. (2018). It can be said that WV treatments will be able to affect microbial biomass, as based on the findings obtained from this study, as Du et al. (2016) and Rui et al. (2014) stated before in their researches.

\section{Conclusion}

Pesticides which are widely used in agricultural practices harm the food safety and/or security, environment, biological diversity and biological chain. This issue affects soil 
productivity and human health in a serious and negative way, and these negative effects become more prominent in time. In accordance with the 2009/128/EC Framework Directives, the usage of pesticides must be minimized, and primarily the low-risk pesticides like bio-pesticides must be taken into consideration. Wood vinegar is a product which has a very low environmental risk and can quickly decay in the soil as a result of microbial activities. At this point, we consider that wood vinegar can be used as a bio-pesticide, i.e. as an alternative to the pesticides. In this study, it has been detected whether wood vinegar used in wheat agricultural eco-system has a negative effect on microbial factors determined in the soil, or not. As based on this, it can be put forth that wood vinegar will be able to be used securely as a pesticide. Additionally, the increase in enzyme activities and productivity may indicate that using WV practically is able to create a positive effect in crop production. Considering wood vinegar treatments, it can be stated that especially its doses and use frequencies have an effect on the microbial factors in soil. It is estimated that the dose of $3.0 \% \mathrm{~mL}$ will especially create a positive effect on the number and activity of biological factors in soil, in general.

\section{REFERENCES}

[1] Ahadiyat, Y. R., Hadi, S. N., Herliana, O. (2018): Application of wood vinegar coconut shell and NPK fertilizer to maintain sustainable agriculture of upland rice production. Journal of Degraded and Mining Lands Management 5(3): 1245.

[2] Aleandri, G. C., Bruni, N., Tomassini, A., Luccioli, E., Vettraino, A. M., Vannini, A. (2012): Trichoderma species with biocontrol activity against nursery soil-borne pathogens. - MP. Journal of Plant Pathology 94: 4.

[3] Anonymous (2016a): Bitki hastalıkları standart ilaç deneme metotları: hububat hastalıkları. - https://docplayer.biz.tr/17727905-Bitki-hastaliklari-standart-ilac-denememetotlari.html (November 17, 2016).

[4] Anonymous (2016b): Muş Meteorological Provincial Directorate Records. - November 5, 2016.

[5] Baimark, Y., Niamsa, N. (2009): Study on wood vinegars for use as coagulating and antifungal agents on the production of natural rubber sheets. - Biomass and Bioenergy 33(6-7): 994-998.

[6] Baimark, Y., Threeprom, J., Dumrongchai, N., Srisuwan, Y., Kotsaeng, N. (2008): Utilization of wood vinegars as sustainable coagulating and antifungal agents in the production of naturel rubber sheets. - Journal of Environmental Science and Technology 1(4): 157-163.

[7] Benson, H. J. (2001): Microbiological Applications: A Laboratory Manual in General Microbiology. - McGraw-Hill, New York.

[8] Chalermsan, Y., Peerapan, S. (2009): Wood vinegar: by-product from rural charcoal kiln and its role in plant protection. - As. J. Food Ag-Ind. 189-195.

[9] Chuaboon, W., Ponghirantanachoke, N., Athinuwat, D. (2016): Application of wood vinegar for fungal disease controls in paddy rice. - Applied Environmental Research 38(3): 77-85.

[10] Craze, B. (1990): Soil Survey Standard Test Method; Soil Moisture Content. Department of Sustainable Natural Resources, Melbourne, pp. 1-5.

[11] Du, W., Zhu, Y., Zhang, X., Geng, Y. Lin, P. (2016): Effects of wood vinegar on microbial biomasses and enzyme activity in sandy soil. - Bulletin of Soil and Water Conservation 3: 061. 
[12] Duan, X., Wang, H., Liu, Z., Feng, C., Cui, Y. (2016): Antibacterial activities of wood vinegar from agricultural and forestry wastes dry distillation products. - Southwest China Journal of Agricultural Sciences 29(2): 425-429.

[13] Hagner, M. (2013): Potential of the slow pyrolysis products birch tar oil, wood vinegar and biochar in sustainable plant protection - pesticidal effects, soil improvement and environmental risks. - Thesis, Department of Environmental Sciences Faculty of Biological and Environmental Sciences University of Helsinki, Finland.

[14] Ibrahim, D., Kassim, J., Sheh-Hong, L. Rusli, W. (2013): Efficacy of pyroligneous acid from Rhizophora apiculata on pathogenic Candida albicans. - Journal of Applied Pharmaceutical Science 3(7): 7-13.

[15] Jothityangkoon, D., Koolachart, R., Wanapat, S., Wongkaew, S., Jogloy, S. (2008): Using wood vinegar in enhancing peanut yield and in controlling the contamination of aflatoxin producing fungus. - International Crop Science 4: 253-253.

[16] Kim, D. H., Seo, H. E., Lee, S. Lee, K. (2008): Effects of wood vinegar mixted with insecticides on the mortalities of Nilaparvata lugens and Laodelphax striatellus (Homoptera: Delphacidae). - Animal Cells and Systems 12(1): 47-52.

[17] Koç, İ. (2017): A research on determination of some effects of wood vinegar and pesticides on wheat agroecosystems. - Thesis Doctor of Philosophy, Yüzüncü Y1l University, Institute of Natural and Applied Sciences, Van.

[18] Koc, I., Yardim, E. N., Akca, M. O., Namli, A. (2018): Impact of pesticides and wood vinegar, used in wheat agro-ecosystems, on the soil enzyme activities. - Fresenius Environmental Bulletin 27(4): 2442-2448.

[19] Lee, S., Ahn, B., Cho, S. (2010): Antimicrobial activities of wood vinegar and application as natural fungicides and food preservatives. - Mokchae Konghak=Journal of the Korean Wood Science and Technology 38(4): 341-348.

[20] Mao, Q., Zhao, Z., Ma, X., Li, K. (2010): Preparation, toxicity and components for bitter almond shell wood vinegar. - Nongye Jixie Xuebao/Transactions of the Chinese Society of Agricultural Machinery 41(2): 164-170.

[21] Mendeş, M. (2013): Uygulamalı bilimler için istatistik ve araştırma yöntemleri. - 3. Baskı, Kriter Yayınevi, İstanbul.

[22] Naml1, A., Akça, M. O., Turgay, E. B. Soba, M. R. (2014): Odun sirkesinin tarımsal kullanım potansiyelinin araştırılması. - Toprak Su Dergisi 3(1): 44-52.

[23] Naseby, D. C., Lynch, J. M. (1997): Rhizopshere soil enzymes as indicators of perturbation caused by enzyme substrate addition and inoculation of a genetically modified strain of Pseudomonas fluorescens on wheat seed. - Soil Biology \& Biochemistry 29: 1353-1362.

[24] Nurhayati, T., Roliadi, H., Bermawie, N. (2005): Production of mangium (Acacia mangium) wood vinegar and its utilization. - Journal of Forestry Research 2(1): 1325.

[25] Oramahi, H. A., Yoshimura, T. (2013): Antifungal and antitermitic activities of wood vinegar from Vitex pubescens vahl. - Journal of Wood Science 59(4): 344-350.

[26] Oramahi, H. A., Yoshimura, T., Diba, F., Setyawati, D. (2018): Antifungal and antitermitic activities of wood vinegar from oil palm trunk. - Journal of Wood Science 64(3): 311-317.

[27] Rui, Z., Wei, D., Zhibin, Y., Chao, Z., Xiaojuan, A. (2014): Effects of wood vinegar on the soil microbial characteristics. - Journal of Chemical and Pharmaceutical Research 6(3): 1254-1260.

[28] Saberi, M., Sarpeleh, A., Askary, H., Rafiei, F. (2013): The effectiveness of wood vinegar in controlling Rhizoctonia solani and Sclerotinia sclerotiorum in green house-cucumber. - Int J Agric Res Nat Res 1(4): 38-43.

[29] Shi, Z. Y. (2003): The effects of wood vinegar on soil microorganisms and growth of vegetable seedlings. - M. S. Thesis, China Agricultural University (People's Republic of China), China. 
[30] Tiilikkala, K., Fagernäs, L., Tiilikkala, J. (2010): History and use of wood pyrolysis liquids as biocide and plant protection product. - The Open Agriculture Journal 4(1): 111-118.

[31] Topal, S. (2011): Herbicidal effects of the allelochemicals. - Dumlupınar Üniversitesi Fen Bilimleri Enstitüsü Dergisi (25): 23-26.

[32] Velmurugan, N., Han, S. S., Lee, Y. S. (2009): Antifungal activity of neutralized wood vinegar with water extracts of Pinus densiflora and Quercus serrata saw dusts. - Int. J. Environ. Res. 3(2): 167-176.

[33] Winer, B. J., Brown, D. R., Michels, K. M. (1971): Statistical Principles in Experimental Design. Vol. 2. - McGraw-Hill, New York.

[34] Yardim, E. N. (1996): The impacts of chemical management of pests, diseases and weeds on invertebrates in tomato agroecosystems. - Thesis Doctor of Philosophy, The Ohio State University, USA. 